Jacek Wódz

Zakład Socjologii Polityki

Uniwersytet Śląski

\title{
POLITYCZNE WYMIARY ZRÓŻNICOWAŃ REGIONALNYCH W POLSCE. KILKA REFLEKSJI Z PUNKTU WIDZENIA SOCJOLOGII I ANTROPOLOGII POLITYKI
}

\section{WPROWADZENIE}

Debata na temat polskich regionów ma już sporą literaturę, więc podejmowanie jej po raz kolejny musi być jakoś uzasadnione. Najprościej byłoby powiedzieć, że - jak dotąd - w tej debacie dominują głosy ekonomistów i geografów ekonomicznych, nie zaś socjologów. Ale powód mego zainteresowania tym zagadnieniem jest nieco inny. Otóż, ze względu na moje ponad 20-letnie stałe kontakty z Instytutem Studiów Politycznych w Bordeaux, gdzie przez wiele lat wykładałem antropologię polityki Europy Środkowej i Wschodniej, doszedłem do wniosku, że w naszym polskim podejściu do problematyki regionów jest stosunkowo mało refleksji właśnie z punktu widzenia socjologii i antropologii polityki. Zwłaszcza podejście antropologiczno-socjologiczne wydaje mi się szczególnie ciekawe (Wódz J. 2009, a także Wódz J. 2012), bowiem kulturowe podejście do tożsamości politycznej regionów jest u nas stosunkowo rzadko wykorzystywane. Sprawom tym poświęciłem w ostatnich latach kilka tekstów, zaczynając od analizy dynamiki odradzania się i rodzenia się nowych tożsamości regionalnych (Wódz J. 2006), a kończąc na kilku tekstach poświęconych specyfice Górnego Śląska (Wódz J. 2010).

Tekst ten dotyczy polskich regionów, ale nie można dyskutować o regionach bez kilkuzdaniowego przypomnienia, że Polska, jako niepodległy kraj, odrodziła się w 1918 r. i problemem ówczesnej władzy nie było zainteresowanie regionami, lecz scalanie kraju złożonego z ziem trzech zaborów. Naturalne więc było, że przy pełnej świadomości wielkich różnic między poszczególnymi regionami zasadnicze zadanie polegało na budowaniu państwa scentralizowanego z jednolitą wizją świadomości narodowej.

Po II wojnie światowej, po bardzo znaczącej zmianie granic i wielkich migracjach powstała Polska regionalnie zupełnie odmienna od II RP, ale lata braku 
pełnej wolności i model państwa scentralizowanego realizowany przez ówczesną władzę też nie sprzyjał rozwojowi regionów i rozwojowi debaty o ich specyfice czy roli politycznej. Dopiero po czerwcowych wyborach roku 1989 zauważyć można pojawienie się na szerszą skalę problemu identyfikacji społecznej z regionem. Tu symboliczną rolę odegrało przyporządkowanie senatorów do województw, pierwsi senatorowie chętnie sami siebie nazywali senatorami „takiej to a takiej ziemi". Oczywiście nie znaczy to, że w tych regionach, w których poczucie odrębności było silne, nie było oznak rewindykacji tożsamościowych jeszcze przed 1989 r. (Wódz K. 1994), ale sytuacje wcześniejsze zdarzały się w swoistej pustce normatywnej, nie mogły być odnoszone do żadnych instytucji czy też ośrodków władzy.

Jeśli więc przyjąć, że (z pewnymi wyjątkami) szersza debata nad tożsamością regionalną zaczyna się po 1989 r. to istotnym jej elementem było odniesienie się do wcześniejszego modelu tożsamości narodowej (Wódz K, Wódz J. 1999). Jednocześnie podkreślić trzeba, że w polskiej socjologii toczyła się też debata teoretyczna nad samym pojęciem tożsamości społecznej, co wyposażyło badaczy w niezbędne narzędzia analizy (Bokszański 1989).

Na zakończenie tego wprowadzenia wypada zaznaczyć, że tekst ten jest tekstem dedykowanym; nie samoistnym studium problemu, a raczej refleksją, którą chcę się przyłączyć do jubileuszu Koleżanki.

\section{PRAWO JAKO DETERMINANTA RZECZYWISTOŚCI SPOLECZNEJ}

Rzeczywistość społeczna regulowana jest przez wiele czynników, wśród których jeden z najważniejszych stanowi prawo. Zmiana ustroju kraju, a zwłaszcza zmiana ustroju definiującego administracyjnyego podział i zasady funkcjonowania jednostek terytorialnych, to był bardzo ważny element kształtujący analizowane przeobrażenia stosunku mieszkańców do swoich wsi, miast i regionów. Gdyby na interesującą nas problematykę spojrzeć z punktu widzenia nowocześnie rozumianego systemu politycznego (zawierającego trzy części - normatywno-prawną, opisu praktyk wyłaniania i funkcjonowania reprezentacji politycznej oraz kultury politycznej), a nie tylko z punktu widzenia ustroju, to należałoby powiedzieć, że owe ramy normatywne, o których chcemy mówić, są w całości swej istotnym elementem dynamiki przemian tożsamości polskich zbiorowości terytorialnych. Mimo że pierwszą w nich rolę odgrywa system prawa (głównie prawa konstytucyjnego i administracyjnego), to przecież równie ważne są demokratyczne praktyki wyłaniania reprezentacji politycznej i kultura polityczna na szczeblu lokalnym i regionalnym. Taka analiza znana jest np. z badań francuskich, gdzie 
praktyka społeczna tworzenia się nowoczesnych regionów jest też stosunkowo młoda, gdyż państwo to ma przecież stare, jakobińskie tradycje centralistyczne (Mabileau 1994, Sadran 1992).

Nie można nie wspomnieć o pierwszych ustawach samorządowych z roku 1990, które choć dotyczyły gmin, nie zaś województw/regionów, to stały się polem pierwszych doświadczeń samorządności terytorialnej. I to właśnie na poziomie lokalnym Polacy uczyli się m.in. definiowania swych problemów społecznych, co jest niezbędne dla późniejszego kształtowania modeli działania lokalnych aktorów społecznych (Wódz J. 1990). Na tym też poziomie powstawały wzory aktywności, przekładalne na poziom działań politycznych, bo tak właśnie w Polsce kształtowały się (głównie poprzez tzw. komitety obywatelskie) modele reprezentacji politycznej zapoczątkowane na początku lat 90 . ubiegłego wieku w radach gmin (Wódz J. 2004). Właśnie na terenie lokalnym mieliśmy też szansę dłuższej analizy procesów wyłaniania w , ale i ewolucji składu owej reprezentacji politycznej (Seiler, Wódz J., Wódz K. 1997), a w miastach mogliśmy sprawdzić możliwość funkcjonowania partnerstwa społecznego władzy samorządowej z różnego rodzaju aktorami społecznymi (Wódz J. 2002, 1999). Wreszcie to na tym poziomie zaczęły efektywnie funkcjonować praktyki komunikacji społecznej (Wódz K., Wódz J. 2003) między władzą lokalną a obywatelami i między różnego typu innymi aktorami życia społecznego. Słowem, jeśli powrócić tu do przypomnienia wcześniej ewokowanego, nowocześnie rozumianego systemu politycznego, to na szczeblu lokalnym, dzięki powstaniu owych nowych ram normatywnych, pojawiła się praktyka społeczna, która budowała nowe formy identyfikacji mieszkańców z ich zbiorowością terytorialną. Oczywiście, tym razem szło jeszcze tylko o poziom lokalny, choć trzeba przyznać, że już z początkiem lat 90 . zaczęto mówić o powstaniu reprezentacji także na poziomie wojewódzkim. Były to jednak organy będące reprezentacją pośrednią (delegaci rad gmin) i nie odegrały większej roli w kształtowaniu podstaw tożsamości regionalnej. Dopiero z końcem lat 90. rząd Jerzego Buzka podjął próbę pewnej decentralizacji, wprowadzając w wyniku tzw. reformy administracyjnej nowy podział na województwa (16, zamiast poprzednich 49) i wyposażając owe województwa w samorząd terytorialny na poziomie ponadlokalnym. Trzeba jednak przypomnieć, że owa reforma z 1998 r. stworzyła dwa rodzaje samorządu terytorialnego na poziomie ponadlokalnym - powiatowy, który okazał się swoistym nieporozumieniem, bowiem nie wpłynął na powstanie poczucia przynależności społecznej do swego powiatu i pozostaje strukturą czysto formalną, oraz wojewódzki, który stworzył ramy normatywne dla tworzenia się poczucia przynależności do swego województwa - regionu. Jednak, zanim wskażemy na pewne systemowe podstawy owej tożsamości regionalnej, 
warto zwrócić uwagę na to, co działo się przez kilka miesięcy poprzedzających wprowadzenie owej reformy administracyjnej.

Otóż, w ramach tzw. konsultacji społecznych, stanowiących element tworzenia nowych rozwiązań ustrojowych, odbyła się w kraju, często ożywiona, debata publiczna nad dokładnym kształtem nowego podziału kraju. Trzeba tu podkreślić, że typ rozwiązań ustrojowych zakładający treść i zakres samorządności wojewódzkiej nie wywołał szczególnego zainteresowania obywateli (choć z punktu widzenia ustrojowego był niezwykle ważny, określał bowiem stopień faktycznej decentralizacji, która w sumie okazała się dość nikła), natomiast wielkie debaty społeczne wiązały się z problemem wielkości przyszłych województw i ich granicami. Okazało się, że poczucie przynależności terytorialnej wzmocnione już zdobytymi doświadczeniami z zakresie samorządności lokalnej pozwoliło elitom poszczególnych miast zbudować pewne konkurencyjne dla planu centralnego wizje przyszłości, co użyte zostało następnie jako argument $\mathrm{w}$ walce o konkretne rozwiązania polityczne, przekładające się później na decyzje o podziale terytorialnym kraju. Można tu wskazać i te „wygrane" debaty (w wyniku takich debat i nacisków społecznych stworzone zostały ostatecznie poprzednio nieprzewidywane województwa opolskie i świętokrzyskie) i te „przegrane” (np. mimo mobilizacji elit społecznych Bielska Białej czy Słupska, nie udało się tym miastom stworzenie województw, w których miasta te byłyby stolicami). Ale nawet w wypadku owych debat „przegranych" uzyskano wiele - była to mobilizacja społeczna, był to nowy asumpt do konsolidacji lokalnych elit, co - jak można dziś obserwować - owocuje w postaci rozwoju tych miast.

Wprowadzenie w życie reformy Buzka stworzyło nową sytuację normatywną. Samorządność wojewódzka, o której zaczęto także mówić jako o samorządności regionalnej, wymagała dla swego funkcjonowania stworzenia zarówno nowych form wyłaniania reprezentacji politycznej na szczeblu regionalnym, jak i stworzenia pewnych praktyk komunikacji politycznej, pozwalających na organizację społeczeństwa obywatelskiego, a więc tego elementu systemu politycznego, który kojarzony jest również z kulturą polityczną. O ile jednak na płaszczyźnie normatywnej sprawa ta wyglądała stosunkowo jasno, o tyle realia społeczne, w których miałyby powstawać trwalsze elementy owej kultury politycznej, okazały się bardzo różne w różnych województwach. Trzeba bowiem pamiętać, że nowe województwa zaistniały w nowych granicach, zaś poprzedzające samą decyzję debaty publiczne spowodowały mobilizację społeczną, która w wypadku braku sukcesu nie tylko stanowiła swoiste niebezpieczeństwo powstania pewnych nastrojów braku współdziałania (by nie powiedzieć wręcz tendencji do poszukiwania dróg separacji od 
województwa, z którym nie chciano być kojarzonym), ale także tworzyła sieć komunikacji politycznej niesprzyjającej integracji wewnętrznej nowych jednostek administracyjnych.

W sytuacji słabości polskich partii politycznych, ich braku struktur na niższych szczeblach jednostek terytorialnego podziału kraju, wreszcie braków kadrowych, w trakcie pierwszych wyborów do sejmików wojewódzkich mieliśmy do czynienia z dużą różnorodnością podmiotów politycznych, często o charakterze doraźnym, niestałym, co należy odnotować jako swoiste osłabienie szansy na wykorzystanie owej nowej sytuacji normatywnej dla dynamizowania procesów tworzenia się tożsamości regionalnej. Nie bez znaczenia był też fakt, iż istniejąca pod koniec lat 90. sieć regionalnych stacji telewizyjnych i radiowych (mam tu na myśli media publiczne), a także główne ośrodki wydawania prasy związane były z dawnym podziałem kraju. Dostosowywanie ich do funkcji mediów w komunikacji politycznej w warunkach nowych województw zabrało trochę czasu, co też można uznać za istotny element opóźniania się budowania tożsamości regionalnej w nowych warunkach.

\section{DYNAMIKA PROCESÓW TWORZENIA I ODTWARZANIA TOŻSAMOŚCI W POLSKICH REGIONACH ORAZ JEJ KORELATY}

Po przełomowych latach 1989/1990, gdy Polacy zaczęli korzystać z wolności wypowiedzi, zaczęto coraz śmielej podnosić w dyskursie publicznym liczne różnice kulturowe i społeczne, jakie charakteryzują poszczególne większe i mniejsze zbiorowości terytorialne w naszym kraju. Dość szybko zdano sobie sprawę, że w sytuacji, w której dla funkcjonowania demokracji lokalnej konieczna jest mobilizacja społeczna, nie można opierać się na jednym tylko modelu symbolicznym. Tak się bowiem złożyło, że dla integracji trzech części rozbiorowych przyjęto $\mathrm{w}$ okresie międzywojennym pewien model symboliczny polskiej tożsamości, który miał ułatwiać tę integrację, później, z zupełnie innych względów i po koniecznych modyfikacjach, taki model okazał się przydatny po II wojnie światowej zarówno dla ówczesnej władzy, jak i dla stanowiącego ostoję opozycji politycznej Kościoła katolickiego, co w sumie dało nam właśnie na początku lat 90. ów, umownie tu nazywany „romantycznym”, model tożsamości narodowej. Jego analiza jest tu konieczna, stał się on bowiem realnym zjawiskiem, w sytuacji, gdy kształtowanie pierwszych form faktycznie funkcjonującej tożsamości regionalnej porównywane było właśnie z tymże modelem „romantycznym”. Było to widać już w na początku lat 90., gdy uwidoczniły się kulturowe pozostałości dawnych podziałów zaborowych, vide zaistniałe wówczas w Małopolsce 
tendencje do nawiązania do tradycji galicyjskiej (Bonusiak, Buszko 1994), by nie wspominać na razie przypadku Górnego Śląska.

Na czym polegał ów model ,romantyczny”? Otóż idzie nam o pewną zbitkę symboliczną, w której polskość miała być, po pierwsze, jednolita symbolicznie i oparta na wspólnych korzeniach historycznych, po drugie, owa polskość, gloryfikując wspólnotę symboli, z pewną obawą tolerowała odmienności symboliczne poszczególnych regionów, widząc w niej swoiste zagrożenie dla istoty państwa. Z kolei państwo też widziane było $\mathrm{w}$ formie wyidealizowanego symbolu, bez odniesienia do realiów społecznych konkretnego państwa. Stąd w tym modelu państwo realne to było państwo „obce”, a państwo idealne było państwem „naszym”. Wartości narodowe były w tym modelu nierozerwalnie związane z polską wersją katolicyzmu (np. kult maryjny nie bardzo wiadomo czy bardziej katolicki, czy bardziej narodowy), wreszcie w tym modelu istniała swoista pogarda dla pragmatyzmu i idealizacja stolicy jako wartości symbolicznej, równie ważnej dla wszystkich Polaków. To, oczywiście, wynikało z historii i nie miejsce tu by uzasadniać historyczne powody wytworzenia się takiego modelu. Państwo scentralizowane z różnych, czasem sprzecznych wobec siebie, powodów służyło dobrze i Polsce międzywojennej i Polsce powojennej i wreszcie Kościołowi katolickiemu, z tym, że dla Kościoła centrum symbolicznym nie była Warszawa, tylko Częstochowa. Otóż, nie ulega wątpliwości, że model ten poparty sposobem, w jaki nauczano historii Polski czasów rozbiorów i całego XIX i XX w., umacniał ten sposób widzenia polskości. Nie chciano sobie zdać sprawy z tego, że w modelu tym symbolika pochodziła głównie, jeśli nie prawie wyłącznie, z historii Kongresówki, że nie było w niej prawie wcale symboli pozostałych ziem, że wreszcie brak symboliki pochodzącej z poszczególnych regionów stawiał tych, którzy chcieli na początku lat 90. budować, czy odbudowywać, tożsamość regionalną w nieco dwuznacznej pozycji oponentów wobec tego modelu tożsamości polskiej. Jeśli się chce znaleźć dziś przyczynę konfliktowego często charakteru owej dynamiki tworzenia się tożsamości regionalnej w owych latach, to nie można pominąć istnienia owego „romantycznego" modelu polskiej tożsamości narodowej.

Innym ważnym problemem było miejsce, jakie w tym modelu odgrywała Warszawa. Oczywiście idzie tu o miejsce symboliczne. Od czasów odzyskania niepodległości w 1918 r. Warszawa obrastała w znaczenia symboliczne, ale i jej symbole były wprowadzane do świadomości Polaków jako elementy spajające cały naród (np. symboliczne znaczenie powstania warszawskiego czy też hasło - „Cały naród odbudowuje swoją Stolicę"), co spowodowało, że początek procesów budowania nowej tożsamości regionów (które też przecież w swych konkretnych granicach były jednostkami nowymi) przynajmniej w niektórych swych wymiarach musiał się charakteryzować swoistą konfliktowością symboli 
regionalnych i symboli Warszawy jako stolicy państwa, które realnie było państwem scentralizowanym, przeciwnym wzrostowi znaczenia regionów. Nie jest więc zaskoczeniem, że przynajmniej w niektórych przypadkach dynamika budowania nowego wyrazu symbolicznego regionów oparta była na zaprzeczaniu roli Warszawy (np. na Śląsku w dyskursie publicznym pojawiały się często takie elementy, jak wskazywanie na symbolikę Warszawy jako „obcą” ludności Śląska, czy też wskazanie na patologiczną rolę stolicy w okresie kilku ostatnich dziesięcioleci, aż po koncepcję „kolonizacji wewnętrznej” Śląska przez władzę z Warszawy). Można to nazwać techniką perswazyjną tworzenia z symboli Warszawy swoistego „czarnego ekranu”, na tle którego nowa, własna symbolika regionalna wygląda zawsze jasno. Ten element procesu tworzenia się w Polsce nowej tożsamości regionalnej nie był, jak dotąd, nigdy głębiej zbadany (Wódz J., Wódz K. 1998).

Obserwując opisywane wyżej zjawiska, z jednej strony, budowania elementów własnej symboliki regionalnej, z drugiej - przeciwstawiania tych elementów owemu modelowi nazwanemu tu przez nas skrótowo modelem ,romantycznym", nie sposób nie zauważyć, że warunkiem powodzenia takich działań jest właśnie dezagregacja owego modelu „romantycznego". Stąd można pokusić się o hipotetyczne stwierdzenie, że im większe są dziś symptomy owej dezagregacji, tym znaczniejsze są siły napędowe powstawania tożsamości regionalnej w naszym kraju.

W literaturze socjologicznej poświęconej problematyce regionów dominujące miejsce zajmują te opracowania, które sytuują region w jego przeszłości pełnej własnych, znaczących faktów historycznych, z których wynika późniejsza wspólnota kulturowa, językowa, często także ekonomiczna, najczęściej również dająca jakieś podstawy do swoistych cech społecznych ludności. Czasem pojawia się też odniesienie do jakichś cech czy dokonań politycznych, pozwalających mówić o swoistej regionalnej kulturze politycznej. Gdy czyta się takie analizy, pojawia się pytanie - czy można w dzisiejszej Polsce tak właśnie patrzeć na problematykę regionalną? Otóż odpowiedź musi być jednoznaczna - nie, nie można. Zresztą nie tylko w Polsce, chyba w całej umownie rozumianej Europie Środkowej (Wódz J. 2001), cechą bowiem tej części Europy jest opóźnienie (w stosunku do Europy Zachodniej) formowania się tożsamości tak narodowych, jak i regionalnych. Jest to po prostu efekt panowania tutaj trzech mocarstw i faktu, iż dopiero po I wojnie światowej, w sposób zresztą czasem dość sztuczny (choć paradoksalnie nazwany „etnograficznym”), wytyczono granice nowych państw, co spowodowało wiele komplikacji, takich jak duża skala w tej części Europy mniejszości narodowych, konfliktowy charakter granic itd. Do tych kłopotów należy też do dziś dnia dość powszechny w Europie Środkowej problem kształtowania reprezentacji politycznej 
na poziomie regionalnym (Wódz J. 2005). Do problemu tego powrócimy nieco dalej. Ale sytuacja Polski jest jeszcze bardziej skomplikowana. Po II wojnie światowej, gdy wytyczano granice naszego kraju w tym kształcie, który obowiązuje do dziś, dokonano „przesunięcia” kraju o kilkaset kilometrów na zachód, w wyniku czego pojawiły się wielkie migracje, zarówno z dawnych ziem polskich na zachód w nowe granice Polski, jak i migracje ludności niemieckiej na zachód do ówczesnych czterech stref okupacyjnych Niemiec. I choć fakty te są powszechnie znane, to trzeba je przypomnieć, by skazać na specyficzny w wielu naszych regionach fakt krótkiego przywiązania ludności do terytorium przez nią zamieszkiwanego.

Mówiąc bardzo skrótowo, trzeba najpierw wyróżnić dwie sytuacje. Pierwsza to regiony, w których istnieje co najmniej kilkupokoleniowa tradycja przywiązania do terytorium regionu, i druga, w której to przywiązanie datuje się dopiero od drugiej polowy lat 40 . To są sytuacje faktycznie dzielące Polskę na tę część (głównie wschodnią, środkową i cześć południowej), gdzie mamy do czynienia z regionami o wielopokoleniowym poczuciu przynależności do terytorium, oraz tereny północne i zachodnie, oczywiście z wyjątkiem Wielkopolski, gdzie poczucie to jest oparte na krótkiej historii zaczynającej się najwcześniej w drugiej połowie lat 40., a często później. Generalnie uważa się, że Polska jest krajem raczej ubogim w tradycyjne, historyczne regiony, a sytuacja, gdy tożsamość regionalną w nowoczesnym sensie budować można tylko poprzez odwołanie się do prospektywnej wizji, do jakiejś wspólnej przyszłości, wspólnego planu kształtującego przyszłość, dotyczy około połowy polskich województw. Stąd w naszych warunkach istotną rolę $\mathrm{w}$ dynamice budowania tożsamości regionalnej stanowi rozbudowywanie treści tzw. prospektywnej definicji regionu (Wódz J. 1995).

Popatrzmy więc na regiony pozostałe, te, w których można mówić o wielopokoleniowym przywiązaniu ludności do terytorium. Otóż i tutaj sytuacja nie jest zupełnie jasna, bowiem - z grubsza biorąc - można rozróżnić regiony typowo historyczne (głównie te usytuowane w centrum i niektóre usytuowane na wschodnie i południowym wschodzie), regiony o kulturze pogranicznej, gdy część ludności swe przywiązanie symboliczne wiąże z terytorium znajdującym się także za granicą państwa, i wreszcie regiony o charakterze kulturowo-pogranicznym, choć $\mathrm{w}$ obecnych granicach znajdujące się w dalszej odległości od granicy (Wódz J. Wódz K. 1995, a także Wódz J. 1994). Na przykład regiony pogranicza wschodniego mają charakter pograniczny, często odwołują się także do swoistego zapasu symbolicznego związanego z terytoriami znajdującymi się dziś poza granicami kraju, co powoduje, z jednej strony, pewną łatwość kontaktu kulturowego, z drugiej zaś - ogranicza możliwość korzystania z tego zapasu w konkretnych działaniach przyszłościowych. Regionami o charakterze regionów kulturowo pogranicznych, choć znajdującymi się dziś na terenie niepogranicznym, 
są województwa śląskie i opolskie. Obydwa te regiony kulturowo nawiązują i to czasem bardzo mocno (problematyka mniejszości narodowej niemieckiej) do swej przeszłości pogranicznej, co stanowi o ich specyfice tożsamościowej; dodatkowo w województwie śląskim mamy do czynienia z wyraźną mniejszościową grupą kulturową specyficzną dla tego regionu (Wódz J., Wódz K. 1999).

W związku z tym co powiedziano wyżej warto się zastanowić, rozważając dynamikę procesów tożsamościowych w polskich regionach, do jakich odwołań, zarówno symbolicznych, jak i praktycznych, sięga się najczęściej w tych regionach, w momencie, gdy buduje się obraz kulturowy regionu. Przypomnijmy, że regiony, a właściwie samorządy wojewódzkie, mają ustawowy obowiązek budowania takich obrazów w związku z przygotowywaniem strategii rozwoju regionalnego. Praktyka polityczna dwóch już dotychczasowych wyborów do samorządu wojewódzkiego (do sejmików wojewódzkich) wyraźnie wskazuje, że w trakcie kampanii wyborczych występuje także wyraźne zapotrzebowanie społeczne na takie odwołania. Pozwalają one identyfikować kandydatów czy też partie polityczne z pewnymi sposobami korzystania z zapasu symbolicznego właściwego regionowi, a także pozwalają przekładać elementy współtworzące tożsamość na wizje przyszłości regionu (Wódz K., Wódz J. 2001).

Regiony o krótkim przywiązaniu do terytorium, regiony, które nie mają w polskich realiach charakteru historycznego, w małym stopniu korzystają ze wspólnej symboliki, w o wiele szerszym stopniu natomiast budują swe obrazy przyszłości na pewnej wizji. Stąd np. w strategiach rozwoju regionalnego elementem budzącym poczucie wspólnoty regionalnej są najczęściej bądź to warunki naturalne (np. góry czy morze) i płynące stąd konsekwencje dla sposobu życia ludności, bądź pewne projekty konkretnych dokonań w najbliższej przyszłości. Wyraźnie przy tym widać, że decydującym elementem „filozofii” tych strategii rozwojowych jest pragmatyzm.

W regionach o charakterze historycznym mieszczących się w środkowych częściach kraju dość często dla budowania wizerunku regionu korzysta się z symboli związanych z historią tak poszczególnych miejsc, jak i ze wspomnieniem ważnych wydarzeń, jakie miały miejsce na dzisiejszym terytorium regionu. Można też zauważyć, że ów zapas symboli związanych z przeszłością regionu jest używany dla celów pragmatycznych, np. dla promocji turystyki czy dla podwyższenia atrakcyjności regionu w oczach przybyszów z zagranicy.

Nieco inaczej sprawa wygląda $\mathrm{w}$ regionach o kulturze pogranicznej. Tu, co prawda, tak jak to ma miejsce $\mathrm{w}$ regionach historycznych $\mathrm{w}$ centralnej części kraju, korzysta się z symboliki historycznie związanej z terytorium regionu, ale elity tych regionów mają też świadomość, że niektóre elementy kultury regionalnej pozostają w sprzeczności ze wspomnianym wcześniej „romantycznym” modelem polskiej tożsamości. Odnosi się to do symboliki religijnej, tak unickiej, jak 
i prawosławnej, by nie wspomnieć tu o elementach symbolicznych związanych z tradycją żydowską, kiedyś na tych ziemiach bardzo istotną. Jeśli zaś istnieje pewna ciągłość symboli po obu stronach granicy (ukraińskiej, białoruskiej czy słowackiej), to element ten jest używany w bardzo specyficzny sposób - dowartościowywany wewnątrz regionu, ale nieeksponowany w obrazie regionu prezentowanym na zewnątrz.

Wreszcie przypadek dwóch województw o kulturze o charakterze transgranicznym pozostających dziś w pewnym oddaleniu od granicy państwa. Przypomnijmy, idzie tu o województwa opolskie i śląskie. W wypadku tych dwóch województw mamy do czynienia $\mathrm{z}$ eksponowaniem symboli specyficznych tylko dla tych ziem, z wyraźnym brakiem odwołań do jakichś symboli ogólniejszych. Jeśli natomiast $\mathrm{w}$ dyskursie publicznym pojawiają się odwołania do problematyki ogólnokrajowej, to często są to odwołania krytyczne, najczęściej bazujące na założeniu, że reszta kraju nie rozumie specyfiki jednego czy drugiego regionu, stąd swoiste „skazanie na samotność” występujące często w tymże dyskursie w województwie opolskim czy śląskim. Przykładowo i tylko przykładowo można tu wymienić powtarzającą się sprawę dwujęzycznych napisów dotyczących nazw poszczególnych miejscowości w województwie opolskim czy też sprawę pomników dotyczących historii tych ziem z czasów, gdy były one jeszcze we władaniu niemieckim. Przypadek województwa śląskiego omówimy osobno, bo zasługuje on na taką analizę, choćby dlatego, że jest najsilniejszym chyba w kraju przykładem nie tylko tworzenia, ale i odtwarzania się pewnych elementów tożsamości regionalnej.

\section{WPLYW ELIT POLITYCZNYCH NA DYNAMIKE BUDOWANIA TOŻSAMOŚCI REGIONALNEJ}

Pisząc poprzednio o roli samorządności terytorialnej, jej ram normatywnych stworzonych ustawami z 1990 r., wskazywaliśmy na powstanie nowej przestrzeni publicznej, ,zagospodarowywanej” dzięki powstaniu reprezentacji politycznej. Wspominaliśmy też, że doświadczenie budowania reprezentacji politycznej na tym najniższym, lokalnym szczeblu tworzy pewien kapitał społeczny dla przyszłych struktur wyższego rzędu, struktur regionalnych. Teraz wypada zastanowić się, jak elity społeczne w nowych województwach/regionach wpływały i wpływają na dynamikę budowania tożsamości regionalnej.

$\mathrm{Z}$ doświadczeń europejskich wynika, że proces tworzenia tożsamości w regionach jest zależny w znacznym stopniu od elit regionalnych (Frognier 1993), od sposobu, w jaki te elity potrafią komunikować się ze społecznością regionu (Mabileau, Tudesq 1992), i wreszcie od tworzenia się nowych form organizacji 
politycznej na poziomie partii politycznych i protopartii o charakterze regionalnym (Seiler 1993). Teza o znaczącym udziale elit społecznych i politycznych w nadawaniu dynamiki procesom tworzenia się tożsamości regionalnej nie wymaga wyjaśnień. Natomiast przyjęcie tej tezy każe zastanowić się nad wielkimi dysproporcjami, jakie pod względem zasobności w elity występują między polskimi regionami. I ta analiza każe nam zwrócić uwagę na kilka faktów znaczących dla interesującego nas tu procesu. Po pierwsze, dysproporcja między Warszawą i jej wpływem na region Mazowsza a pozostałymi wielkimi miastami w kraju i ich wpływem na swe regiony nie może być widziana wyłącznie w kategoriach ilościowych. Dominacja Warszawy daje bowiem efekt mnożnikowy, po prostu duże i różnorodne elity warszawskie same siebie mobilizują (poprzez szeroko rozumiane zjawisko konkurencji), a ich bliskość w stosunku do władzy ciągle jeszcze mocno scentralizowanego państwa czyni ich działania zdecydowanie bardziej skutecznymi, niźli można by to wnosić wyłącznie z samej liczby np. osób wysoko wykształconych czy też liczby instytucji kultury czy nauki. Nie wolno też zapominać, że te znaczące elity czynią i miasto i otaczający je region bardzo atrakcyjnymi dla potencjalnych inwestorów, dla organizatorów różnego rodzaju manifestacji kulturalnych czy naukowych, czy wreszcie dla organizatorów różnych działań politycznych.

Tylko kilka regionów w Polsce, głównie tych, w których mieszczą się mające dłuższe tradycje ośrodki akademickie, może poszczycić się większą skalą elit. Ważne też jest, by właśnie owe ośrodki akademickie czy kulturalne były jednocześnie miejscami samoodtwarzania się elit i by te elity czuły związek z regionem, a nie dążyły wyłącznie do migracji do Warszawy czy też za granicę. Patrząc na Polskę z tego punktu widzenia, trzeba stwierdzić nie tylko wielkie dysproporcje między poszczególnymi regionami, ale także w pewnym sensie patologiczną rolę Warszawy, która często, zwłaszcza w nieco uboższych w elity regionach, stanowi przedmiot pożądania (w Warszawie robi się „,prawdziwe kariery”) dla miejscowych elit, powodując nie tylko drenaż, ale także mniejsze zaangażowanie tych elit w rozwój tożsamości swoich regionów. Zjawisko to z kolei pogłębia już i tak duże różnice między zasobami elit w polskich regionach.

Drugie zagadnienie to komunikacja społeczna. Polska jest krajem o wyjątkowo scentralizowanej sieci mediów. Koncentracja mediów w Warszawie powoduje, że mamy regiony o wyjątkowo dobrze wyposażonej sieci komunikacji społecznej i regiony prawie tej sieci pozbawione. Oczywiście prym wiedzie Warszawa, z tym, że trzeba zaznaczyć, że media ogólnopolskie prawie w całości usytuowane w Warszawie mają małe ambicje oddziaływania regionalnego na Mazowsze. O ile więc podnoszą potencjalne szanse komunikacji wewnątrz regionu, o tyle z tych szans nie zawsze korzystają. Istnieje kilka ośrodków medialnych o większym znaczeniu, gdzie oprócz prasy o zasięgu regionalnym działają też rozgłośnie radiowe 
i przede wszystkim ośrodki telewizyjne. Nie ulega wątpliwości, że możliwości komunikacji społecznej wewnątrz regionu istnieją w Małopolsce, na Górnym i na Dolnym Śląsku, w Wielkopolsce, duże znaczenie mają ośrodki gdański i nieco mniejszy szczeciński, ale już takie miasta stołeczne regionów jak Lublin czy Białystok, mimo posiadania środowiska akademickiego, nie dysponują silną siecią mediów. Można zapytać - a co z pozostałymi? Otóż wyraźnie dziś widać, że regiony o niskiej dynamice rozwoju mają również stosunkowo słabo rozwinięte sieci mediów na poziomie regionalnym, co powoduje, że nie dość, że mają utrudniony start do budowania nowoczesnej tożsamości regionalnej, to jeszcze nie mają sieci komunikacji społecznej, która pozwoliła by im ten dystans do innych regionów nadrobić. Jest to bardzo istotne w perspektywie celu, jaki stawiają sobie regiony polskie po wejściu naszego kraju do Unii Europejskiej, a więc budowania na poziomie regionu społeczeństwa obywatelskiego pozwalającego na doskonalenie sprawowania władzy poprzez partnerstwo społeczne.

Wreszcie ostatni ze wspomnianych wyżej elementów - istnienie struktur politycznych, w postaci partii bądź protopartii pozwalających na wzmocnienie owego wspomnianego wyżej modelu partnerstwa społecznego w sprawowaniu władzy w regionie. Wypada rozpocząć od stwierdzenia, że polski system partyjny jest nadal bardzo słaby, partie nie mają dłuższej tradycji działania w terenie, a mobilizują się tylko w momencie ważnych kampanii politycznych. Jednak podstawową, z punktu widzenia naszego tematu, zasadniczą sprawą jest to, że polskie partie polityczne w zasadzie nie mają tradycji opracowywania długofalowych wizji przyszłości na poziomie niższym niż narodowy. Sytuacja, gdy przyszło im działać na terenie nowych województw, stanowiła dla partii duże wyzwanie. Tylko w największych miastach - stolicach województw - niektóre partie polityczne znalazły dostatecznie dużo kwalifikowanych kadr, by móc uczestniczyć nie tylko w wyborach samorządowych, ale także wypracowywać własne projekty przyszłości dla regionu. $Z$ drugiej strony, można powiedzieć, że tam gdzie partie miały takie możliwości, stały się one elementem wyraźnie dynamizującym budowanie tożsamości regionalnej. Jeśli do tego dochodziła możliwość korzystania z rozwiniętej sieci komunikacji społecznej, to ów efekt dynamizujący ulegał jeszcze wyraźnemu zwiększeniu.

Nieco inaczej przedstawia się sprawa działania w regionie tzw. protopartii. Nazywa się tak zwykle te organizacje czy stowarzyszenia, które w momentach, gdy nie ma potrzeby aktywności politycznej, działają jak zwykłe stowarzyszenia (najczęściej o charakterze terytorialnym), ale gdy zachodzi potrzeba takiej mobilizacji politycznej, jak gdyby zmieniają dyskurs, zaczynają mówić językiem partii politycznych i zachowywać się jak aktorzy polityczni. Nazwa protopartia zakłada, że z takich właśnie aktorów może w przyszłości wyłonić się, na co zresztą mogą wskazać liczne przykłady w Europie, prawdziwa partia polityczna. Otóż istnienie 
protopartii jest zwykle dość silnym czynnikiem dynamizującym tworzenie się tożsamości regionalnej, oczywiście jeśli dana protopartia działa właśnie na terenie regionu. W Polsce można wskazać na kilka przykładów, z których dwa są dość dobrze znane. Mamy na myśli Unię Wielkopolan i przede wszystkim Związek Górnośląski. Obydwie te protopartie prowadziły w połowie lat 90 . bardzo intensywną pracę na rzecz tworzenia się i odtwarzanie się tożsamości regionalnej, obie też zachowywały się często jak partie polityczne (np. Związek Górnośląski zajmował się popieraniem konkretnych kandydatów i konkretnych list wyborczych, opiniował kandydatów na urzędy w regionie itd.). Można, nieco uogólniając te analizę, powiedzieć, że protopartie w naszych warunkach przyspieszają tworzenie się sieci organizacyjnej społeczeństwa obywatelskiego na poziomie regionalnym.

\section{ROLA UNII EUROPEJSKIEJ W KSZTALTOWANIU TOŻSAMOŚCI REGIONALNEJ}

Jeszcze przed reformą administracyjną kraju można było zauważyć w Polsce wyraźny wpływ przygotowania do akcesji do Unii Europejskiej na sposób organizowania się zbiorowości terytorialnych. Jednak dopiero po 1998 r., gdy powstało 16 dużych województw, można mówić o zauważalnym wpływie najpierw przygotowań do akcesji, a potem już działań z pozycji członka Unii na kształtowanie się tożsamości polskich regionów. Nie wchodząc na razie w analizę merytoryczną tego zjawiska, warto zauważyć pewną znaczącą zmianę spojrzenia na istotę tożsamości w regionach. Można chyba bez ryzyka większego błędu uznać, że z chwilą, gdy pojawiła się w nowych województwach szansa korzystania $z$,projektów unijnych”, poszerzone zostało też samo pojęcie tożsamości regionalnej. Do tradycyjnie wymienianych zawsze cech kulturowych, czasem pewnych elementów historii, zaczęto w dyskursie publicznym dodawać także cechy gospodarki, widząc w tym nowy sposób definiowania swego regionu. I choć nie ma żadnych badań na ten temat, to sama obserwacja wydaje się potwierdzać taką hipotezę. Zauważyć można, że Unia Europejska, kreując regiony na podmioty polityki strukturalnej, wymusza pewną samoorganizację społeczną właśnie na poziomie regionalnym. Nie dość tego, w wypadku przedsięwzięć o charakterze gospodarczym Unia wymusza też wyraźnie kreowanie w regionach struktur partnerstwa społecznego dla celów politycznego zarządzania tymi projektami. Fakt ten stał się w wypadku naszych regionów jednym z motorów przesuwania się samego sposobu określania tożsamości regionalnej w kierunku tożsamości prospektywnej. W tej perspektywie można uznać, że „europeizacja” polskiej debaty o regionach i ich tożsamości przyczyniła się do budowania w regionach społeczeństwa obywatelskiego. 
Wypada zacząć jednak od samego problemu definicyjnego. Otóż, w Polsce, gdzie nie ma dłuższej tradycji definiowania regionów, a regionów historycznych jest stosunkowo mało, bez większych zastrzeżeń zgodzono się przyjąć „logikę unijną" zakładającą, że regionem stanowiącym podmiot polityki strukturalnej jest jednostka administracyjnego podziału kraju, w naszym wypadku województwo. Fakt ten przynajmniej w pewnym okresie wpływał na załagodzenie sporów społecznych wynikających z kampanii poprzedzającej ostateczny podział na 16 województw.

Wracając jednak do polityki strukturalnej Unii, nie można nie zauważyć, że wielu polityków, ale i działaczy gospodarczych, zaczęło interesować się rezultatami tej polityki w regionach państw Unii. Ukazały się na ten temat publikacje naukowe (Pietrzyk 1998), zaczęła się wymiana międzynarodowa działaczy społecznych ze szczebla regionalnego, co w oczywisty sposób wpływało też na poszerzenie zakresu zainteresowań kształtowaniem przyszłości regionu we współpracy międzyregionalnej. To, z kolei, stało się ważnym elementem unowocześniania treści tożsamości regionalnej.

\section{PODSUMOWANIE}

Wraz z procesem definiowania się, czy też redefiniowania się, tożsamości regionalnych następuje proces ich polityzacji. Jest to proces zupełnie normalny, bowiem samorządność poprzez systematycznie dokonywane akty wyborów (przecież par excellence politycznych) wymusza taki proces, zwłaszcza że większość polskich partii politycznych, działających na arenie narodowej, nie rozumie potrzeby konstruowania odrębnych programów wyborczych na użytek samorządowych wyborów w województwach. Zresztą polska tzw. klasa polityczna w ogóle nie rozumie tej płaszczyzny uprawiania polityki, co jest widomym dowodem szkodliwości centralizacji i swoistego karlenia demokracji. Najlepszym przykładem polityzacji tożsamości regionalnej jest casus województwa śląskiego (Wódz J. 2012a), ale to jest problem wymagający osobnego podejścia.

Wśród problemów, które z pewnością zyskają w przyszłości na znaczeniu jest rola wielkich miast w kształtowaniu polityki regionalnej (casus Wrocławia, który w zasadzie w pojedynkę, jako samotny podmiot polityczny, kształtuje obraz całego województwa), tworzenie się wielkich aglomeracji jako samoistnych podmiotów politycznych (casus Trójmiasta). Za tym pójdzie problem konieczności rozbicia skrajnie szkodliwego dla demokracji monopolu Warszawy jako w zasadzie wyłącznego ośrodka dyktującego treści komunikacji politycznej. Może wreszcie w polskiej polityce ktoś zauważy, że zróżnicowanie regionalne w takiej postaci, 
jak występuje ono w Polsce, prowadzi do bardzo poważnego mankamentu demokracji - okazuje się bowiem, że faktyczna siła głosu oddawanego w wyborach jest u nas bardzo różna w zależności od tego, w jakim regionie została oddana.

\section{BIBLIOGRAFIA}

Bokszański Z. (1989), Tożsamość, interakcja, grupa, Łódź: Wydawnictwo Uniwersytetu Łódzkiego. Bonusiak W., Buszko J. (red.) (1994), Galicja i jej dziedzictwo, t. I, Historia i polityka, Rzeszów: Wydawnictwo WSP.

Frognier A.-P. (1993), Le role des elites politiques et de la population dans la transition vers le federalisme en Belgique [w:] J. Wódz (ed.), Reorganiser l'espace public. Katowice: Wydawnictwo Śląsk.

Mabileau A., Tudesq A.-J. (eds) (1992), La communication dans l'espace regionale et locale, Bordeaux: CERVL.

Mabileau A. (1994), Le systeme local en France, Paris: Montchrestien.

Pietrzyk I. (red.) (1998), Polityka regionalna Unii Europejskiej w praktyce krajów członkowskich, Kraków: Wydawnictwo AE

Sadran P. (1992), Le systeme administratif français, Paris: Montchrestien.

Seiler D.-L. (1993), Les partis politiques, Paris: Armand Colin

Seiler D.-L., Wódz J., Wódz K. (1997), O reprezentacji politycznej na szczeblu lokalnym, Katowice, Wydawnictwo Śląsk

Sztompka P. (2005), Socjologia zmian społecznych, Kraków: Znak

Wódz J. (1990), Problemy realizacji podmiotowości zbiorowości lokalnych w świetle empirycznych badań nad tadem społecznym i normami społecznymi, Katowice: Wydawnictwo Sl. I. N.

Wódz J. (1994), Les regions transfrontalieres en Europe centrale et orientalne [in:] J. Chevalier, L'identite politique, Paris: PUF.

Wódz J. (1995), Prospektywne widzenie regionu na tle polskich prób regionalizacji kraju. Refleksja socjologiczna, [w:] Wódz K. (red.), Wokót śląskiej tożsamości, Katowice: Wydawnictwo Towarzystwa Zachęty Kultury.

Wódz J. (1999), Le pouvoir municipal en Polotne: quel partenariat entre gouvernement Urban et nouvelles elites sociales?, [w:] V. Hoffmann-Martinot, L. A. Kosiński (eds), Quel partenariat pour la ville, Paris: Pedane.

Wódz J. (2001), Dynamika przeksztatceń tożsamości narodowej w krajach Europy Środkowej $i$ Wschodniej, „Przegląd Europejski”, nr 2 (3).

Wódz J (2002), New Social Partner sof Local Power In Poland, „International Social Science Journal", June.

Wódz J. (2004), Aktywność lokalna, obywatelstwo lokalne, polityka na szczeblu lokalnym, [w:] P. Gliński, B. Lewenstein, A. Siciński (red.), Samoorganizacja spoteczeństwa polskiego: III sektor i wspólnoty lokalne w jednoczacej się Europie, Warszawa: Wydawnictwo IFiS PAN.

Wódz J. (2005), La notion de representation politique aux niveaux local et regional en Europe centrale et orientalne, [w:] E. Nadal, M. Marty, C. Thiriat (eds.), Faire de la politique comparee, Paris: Karthala.

Wódz J. (2006), Dynamika tworzenia się i odtwarzania się podmiotowości społecznej regionów w Polsce, [w:] A. Flis (red.), Stawanie się społeczeństwa, Krakow: Universitas. 
Wódz J. (2009), Nowe szanse antropologii polityki, „Prawo i Polityka”, nr 1.

Wódz J. (2010), Górny Śląsk jako problem polityczny, „Górnośląskie Studia Socjologiczne. Seria Nowa" t. 1.

Wódz J. (2012), Niektore problemy regionalizacji Polski widziane z perspektywy antropologii polityki, [w:] A. Bobko, B. Marek-Zborowska (red.), Równi ale różni, Rzeszów: Wydawnictwo Uniwersytetu Rzeszowskiego.

Wódz J. (1012a), Między ruchem społecznym w skali regionalnej a protopartia i partia regionalna. Kilka refleksji na tle zmian reprezentacji politycznej w regionach Europy, „Górnośląskie Studia Socjologiczne. Seria Nowa", t. 3.

Wódz J., Wódz K. (1995), Regions transfrontalieres et identites en Europe centrale et orientale, „Revue Internationale de Politique Comparee”. vol 2, no 3.

Wódz J., Wódz K. (1998), Dynamika odtwarzania się świadomości regionalnej w Polsce a idea państwa unitarnego. Sprzeczność realna czy pozorna?, [w:] P. Buczkowski, K. Bondyra, P. Śliwa (red.), Jaka Europa? Regionalizacja a integracja, Poznań: Wydawnictwo Wyższej Szkoły Bankowej.

Wódz J., Wódz K. (1999), Czy Ślazacy sa mniejszościa kulturową?, [w:] J. Mucha (red.), Kultura dominujaca jako kultura obca, Warszawa: Oficyna Naukowa.

Wódz K., Wódz J. (1999), Rewindykacje regionalne a proces dekompozycji tradycyjnej tożsamości narodowej Polaków. Przykład Górnego Śląska, „Przegląd Socjologiczny”, t. XLVIII/2.

Wódz K., WódzJ. (2001), Nowe Typy reprezentacji społecznej $i$ politycznej $w$ polskich społecznościach lokalnych i regionalnych, „Regiony Polski”, nr 2(3).

Wódz K., Wódz J. (red.) (2003), Funkcje komunikacji spolecznej, Dąbrowa Górnicza: Wydawnictwo WSB.

Wódz K. (1994), La revendication identitaire en Polotne, [in:] J. Chevallier. (ed.), L'identite politique, Paris: PUF.

Jacek Wódz

\title{
POLITICAL DIMENSIONS OF REGIONAL DISPARITIES IN POLAND. SOME REFLECTIONS \\ FROM THE PERSPECTIVE OF SOCIOLOGY AND ANTHROPOLOGY OF POLITICS
}

\author{
(Summary)
}

The article examines the Polish regional differences after 1990. It shows the evolutionary process of creation and re-creation of a regional identity (from administrative regions to regions of identity). The author characterizes types of political representation in the Polish regions and wonders if the regions are independent entities of the EU policies. The author also asks about the relationships beetwen regions and the center from the perspective of construction of regional development strategies and about the advantages and disadvantages of concentration of capacity building in Warsaw. 